\title{
Evaluation of the Differential Effect of Female Sex Hormones on Hepatic Inflammatory and Apoptotic Markers in a Model of Acute Systemic Inflammation in the Female Rats
}

\author{
Moshira Rateb ${ }^{1}$, Amira Hassouna ${ }^{2}$, Eman Obaia ${ }^{2}$ and \\ Samar Marzouk ${ }^{2}$ \\ Departments of Physiology ${ }^{(\mathbf{1})}$ and Medical Biochemistry ${ }^{(2)}$, \\ Faculty of Medicine, Cairo University
}

\begin{abstract}
The present study was conducted to investigat the differential effect of estradiol benzoate and progesterone on systemic as well as the liver response to experimentally induced inflammatory states.

Materials and Methods: The study was conducted on 48 female albino rats divided into six groups. Groups I and II consisted of non-ovariectomized animals. Ovariectomy was performed for the remaining 4 groups which were allocated randomly to receive one form of the following daily hormonal supplementation: Subcutaneous (SC) Estradiol benzoate $4 \mu \mathrm{g} / 100 \mathrm{~g}$ body weight (BW) , or SC progesterone $5 \mathrm{mg} / \mathrm{kg}$ BW or; combined daily estradiol and progesterone supplementation or no hormonal supplement at all. At the end of three weeks period, acute systemic inflammation was induced by caecal ligation and puncture in all the groups except group I and the animals were sacrificed 24 hours later and both serum and liver tissue were isolated to evaluate inflammatory and apoptotic markers. Results: Ovariectomized animals subjected to systemic inflammation had significantly higher levels of serum Tumor necrosis factor alpha (TNF $), C$ reactive protein and Alanine Aminotransferease (ALT). They also had higher levels of expression of the enzyme inducible nitric oxide sysnthetase (iNOS) in the liver, and of the activity of both cycloxygenase II (COXII) and Caspase 3 enzymes when compared to nonovariectomized animals subjected to systemic inflammation. Daily supplementation of ovariectomized animals with estradiol resulted in a significant reduction of all serum and liver tissue parameters of inflammation and apoptosis when compared to ovariectomized animals with systemic inflammation receiving no supplementary treatment. In contrast, daily supplementation of ovariectomized animals with progesterone resulted in a significant rise of all measured parameters of serum and liver tissue inflammation and apoptosis when compared to their corresponding values in ovariectomized animals with systemic inflammation and receiving no supplementary treatment. Conclusion: Estradiol supplementation that achieves physiological pro-estrus to diestrus levels in ovariectomized animals can reduce the excessive harmful effects of inflammation and apoptois on the systemic and liver tissue level while progesterone supplementation that achieves estrus physiological levels increases the release of inflammatory mediators and liver tissue apoptosis.

Keywords: systemic inflammation, liver, Estrogen, progesterone, apoptosis
\end{abstract}




\section{INTRODUCTION}

Sepsis is a complex syndrome that results from the host response to infection and leads to tissue injury and inflammation. During systemic bacterial sepsis, the involvement of the liver in the inflammatory process seems to play a main role in the cascading events that eventually involve most of the body organs ${ }^{(1)}$. Gram negative sepsis induced largely by bacterial lipopolysaccharides (LPS) stimulates hepatic production of acute phase proteins, such as Creactive protein, serum amyloid $A$ (SAA), CD14, and LPS binding protein (LBP), which may actually function to restrict LPS action ${ }^{(2)}$.

Within the extremely complex cascade of the pathophysiological events representing the systemic inflammatory response, hepatocellular apoptosis has been identified as a crucial step in the induction of the acute liver failure that frequently complicates systemic bacterial sepsis (3). Apoptosis leads to leukocyte migration and attack on parenchymal cells ${ }^{(4)}$ thereby establishing a vicious circle with aggravation of leukocytic inflammation and final cell death. It has been shown that preventing apoptosis in hepatocytes by caspase inhibition suppresses leukocyte transmigration and leukocytedependent liver cell necrosis. ${ }^{(\mathbf{5 , 6})}$

The differential effect of female sex hormones on systemic inflammatory response in various organs has been investigated in several tissues. Some studies have suggested that estrogen therapy in postmenopausal women can increase hepatic $\mathrm{C}$ reactive protein production. ${ }^{(7)}$ and others have shown that it can also increase the production of IL 6 suggesting a pro-inflammatory role for the hormone. ${ }^{(8)}$

However, Wakatsuki et al. ${ }^{(9)}$ have suggested that the dose of estrogen supplementation seems to influence its effect on inflammatory markers where a high dose increases the serum levels of $C$ reactive protein, IL 6 and serum amyloid A while a low dose did not increase such markers. On the other hand, Sunday et al. also suggested that estrogen in experimental animals reduced inflammatory markers in cerebral blood vessels ${ }^{(\mathbf{1 0})}$.

The effect of progesterone on cardiovascular and cerebrovascular function has produced a lot of controversy. Some studies have shown beneficial effects of progesterone, whereas others show little or no effect. For example, progesterone has been shown to produce a positive effect on exerciseinduced myocardial ischemia and on the outcome of experimental stroke ${ }^{(11)}$. However, Sunday et al. ${ }^{(\mathbf{1 0})}$ suggested that progesterone analogues increased the levels of inflammatory markers and exacerbated cerebrovascular inflammatory response.

In the genital tract, Kautschic et $\mathrm{al}^{(\mathbf{1 2})}$ reported that the hormonal environment at the time of pathogen exposure can have a distinct effect on the outcome of a microbial infection. They studied the susceptibility and degree of inflammation encountered in the genital tracts of ovariectomized rats subjected to chlamydial infection. They concluded that estradiol 
supplementation in ovariectomized animals decreases susceptibility; it also seems to have a strong antiinflammatory response. Progesterone, on the other hand, seems to enhance both susceptibility and inflammatory responses. With the combination of hormones used in these experiments, estradiol effect on inflammation predominates whereas progesterone affects primarily susceptibility.

The aim of this limited study was to evaluate the effect of ovariectomy and the differential effect of estrogen and progesterone supplementation in ovariectomized animals on the inflammatory and apoptotic response in a rat model of acute septic systemic inflammation. We measured markers of systemic inflammation in the serum and evaluated the level of expression and activity of several proinflammatory and apoptotic enzymes in liver tissues of different groups of studied animals.

\section{MATERIAL \& METHODS}

\section{Experimental animals}

This study involved 48 female albino rats weighing between 200-240 g. Their age ranged between 9-10 weeks at the start of the protocol. The animals were randomly divided into six groups each consisting of 8 rats. Animals were fed a standard diet and housed in the animal house of Kasr Al-Aini Faculty of Medicine with a 12:12-h light/dark cycle. The protocol for the study has been approved by the Faculty Ethics Committee.

In order to evaluate the differential effect of estradiol and progesterone on the systemic inflammatory response, all groups except groups I and II were subjected to bilateral ventral ovariectomy which was followed by either no hormonal supplementation, a single form of hormonal supplementation or a combined form of hormonal supplementation for three weeks. Groups I and II were subjected to a sham ovariectomy at the beginning of the protocol.

At the end of the three weeks period, induction of systemic inflammation by ileoceacal ligation and puncture then followed in all groups except group I. 24 hours after the ileoceacal puncture was induced, blood samples were obtained under anaesthesia and the animals were then sacrificed and their liver tissue extracted for further analysis of tissue markers of inflammation and apoptosis.

The details of the groups were as follows:

Group I: Control group (C) subjected to sham ovariectomy.

Group II: Sham ovariectomy followed by induction of systemic inflammation three weeks later. (SI)

Group III: Ovariectomy followed by systemic inflammation induction three weeks later. $(\mathrm{Ovx}+\mathrm{SI})$

Group IV: Ovariectomy with daily SC estradiol Benzoate (4ug/100g BW) supplementation followed by Systemic inflammation induction three weeks later. $(\mathrm{Ovx}+\mathrm{E}+\mathrm{SI})$

Group V: Ovariectomy with daily SC Progesterone supplementation ( $5 \mathrm{mg} / \mathrm{kg}$ BW) followed by systemic inflammation induction three weeks later $(\mathrm{Ovx}+\mathrm{P}+\mathrm{SI})$

Group VI: Ovariectomy with daily estradiol benzoate and progesterone supplementation followed by systemic 
inflammation induction three weeks later. $(\mathrm{Ovx}+\mathrm{E}+\mathrm{P}+\mathrm{SI})$

Parameters measured

Bio-Chemical Parameters:-

Blood samples were taken retroorbitally under anesthesia (Intraperitoneal injection of ketamine 100 $\mathrm{mg} / \mathrm{kg}$ and xylazine $2.5 \mathrm{mg} / \mathrm{kg}) 24$ hours after induction of systemic inflammation states in order to evaluate the following:

a. The degree of the inflammation and sepsis:

Through measurement of TNF $\alpha$ : Serum TNF- levels were measured by ELISA according to the manufacturer's instructions (Biosource, USA) according to the principle of Mizutani et al. ${ }^{(13)}$

b. The level of liver affection:

Through measurement of liver enzymes and $C$ reactive protein: To assess hepatocellular injury, serum ALT levels were measured by using the Opera Clinical Chemistry System (Bayer, Tarrytown, NY).

$C$ reactive protein was evaluated according to the principle of Gewurz (14) by Eliza technique using kits purchased from DIA MED.

c. Estrogen and progesterone levels: Estrogen and progesterone levels were estimated in serum samples taken from different groups using radioimmunoassay described by Johnson et al. (15) for estradiol (Roche diagnostics corporation, Indianapolis, IS, USA) and by Hiborn and Krahn (16) for progesterone (Diagnostic products corporation Los Angeles, CA,. USA).

Analysis of iNOS expression in liver homogenates

The rats were sacrificed and the liver excised and about $30 \mathrm{mg}$ of fresh tissue was homogenized in $175 \mathrm{uL}$ RNA lysis solution which contains guanidinum thiocynate and $\mathrm{BB}$ mercaptoethanol and was centrifuged at $10.000 \mathrm{rpm}$ for 10 minutes at $4^{\circ} \mathrm{C}$. Then, the supernatants were kept frozen at $-80^{\circ} \mathrm{C}$ till examination for expression of iNOS by RT-PCR. Total RNA was extracted from liver tissue using SV total RNA isolation system (Promega Madison, USA) according to the method described by Chomzanschi and Sacchi ${ }^{(17)}$. About 5 ug of RNA was reverse transcribed and amplified using one step RT-PCR kit supplied by Ziagen (Valencia, California, USA). Two primer sets were used, one for the target gene (iNOS) and the other for the housekeeping gene (B-activin). Inducible NOS forward primer 5CAG GAC CAC ACC CCC TCG GA-3 and reverse primer 5 -AGC CAC ATC CCG AGC CAT GC-3 were used and the PCR product was 537bp. Forward B activin primer (5 TGTT GTCCC TGTATGCCTCT3) and reverse primer 5 TAA T GT CAC GCA CGA TTT CC3 ) were used and the PCR product was 206bp.

The PCR mixture contained 10ul of 10x PCR buffer, 2ul of $25 \mathrm{mM}$ $\mathrm{MgCl} 2$, 2ul of $10 \mathrm{mM}$ dNTPS mix, 2.5 units of taq DNA polymerase and $100 \mathrm{pmol}$ of each forward and reverse priers in a total volume of $100 \mathrm{uL}$. The mixture was processed for 40 cycles in a thermal cycler. The PCR cycling conditions were $94^{\circ} \mathrm{C}$ for $1 \mathrm{~min}$ for denaturation followed by $62^{\circ} \mathrm{C}$ for 1 min and $72^{\circ} \mathrm{C}$ for $1 \mathrm{~min}$. Following the final cycle, final extension at $72^{\circ} \mathrm{C}$ for 10 min was performed.

Gel electrophoresis: $10 \mu \mathrm{l}$ of PCR product was analyzed on $2 \%$ agarose 
gel with ethidium bromide staining and the product was visualized on ultraviolet transilluminator, then gel documentation was performed. PCR products were semi-quantified by using a gel documentation system (Bio Doc Analyze) supplied by Biometra.

\section{Caspase 3 activity and COXII.}

About $0.5 \mathrm{~g}$ of liver tissue was dissected and perfused with PBS (PBS).

$30 \mathrm{mg}$ of fresh liver tissue was homogenized in extraction buffer and centrifuged and $10.000 \mathrm{rpm}$ for 15 $\mathrm{min}$, at $4^{\circ} \mathrm{C}$. The supernatant was stored at $-80^{\circ} \mathrm{C}$ for one month for COXII (assay design,Victoria, Canada) and Caspase3 activity immunoassay (Quantikin R and D systems, Minneapolis, USA) following the manufacturer's instructions.

\section{Methods}

\section{Induction of ovariectomy in Female rats:}

Ovariectomy was performed in groups III, IV, V, and VI at the start of the protocol while in group I and II, a sham operation was performed.

Animals in groups III, IV, V and VI were anaesthetized by intraperitoneal injection of ketamine (100 $\mathrm{mg} / \mathrm{kg}$ ) and xylazine $(2.5 \mathrm{mg} / \mathrm{kg})$. The animals were then bilaterally ovariectomized (OVX) through a midventral incision three weeks before induction of systemic inflammation.

In groups I and II, the skin and muscle incisions were performed under anaesthesia but no ovariectomy was performed and the wound was sutured under aseptic conditions as in the other groups.

\section{Hormonal replacement:}

Ovariectomized animals (OVX) received hormonal replacement for three weeks before induction of systemic inflammation. The treatment was in the form of daily subcutaneous injections (SC) of either estradiol benzoate or progestererone or both forms of treatment according to the group the animals belonged to. Estradiol benzoate was given in the dose of $4 \mu \mathrm{g} / 100 \mathrm{~g}$ (BW) in $200 \mu \mathrm{l}$ oil while progesterone was injected in the dose of $5 \mathrm{mg} / \mathrm{kg} \mathrm{BW}$ in oil. ${ }^{(\mathbf{1 2 , 1 8})}$

Estrogen and progesterone were purchased as ampoules of estradiol benzoate and progesterone produced by Misr company for pharmaceuticals. Induction of systemic inflammation

Animals were anesthetized with an intra -peritoneal injection of ketamine $(100 \mathrm{mg} / \mathrm{kg})$ and xylazine $(2.5 \mathrm{mg} / \mathrm{kg}$ ) then subjected to a midline ventral laparotomy with exposure and isolation of the caecum. The caecum was tied off $1 \mathrm{~cm}$ from the end and punctured with a single hole by using a 21-gauge needle. Animals were resuscitated with $2 \mathrm{ml}$ of sterile saline administered subcutaneously after closure of the wound. ${ }^{(19)}$

\section{Statistical analysis}

Data are expressed as mean $\pm \mathrm{SD}$. Groups were compared using Student's t-test or by ANOVA with Post hoc for analysis for statistical significance between groups.

A p-value less than 0.05 was considered significant. 


\section{RESULTS}

\section{Estrogen and Progesterone}

Ovariectomy was associated with a significant reduction in the levels of estrogen in animals subjected to systemic inflammation (group III) when compared to control (group I) $(8 \pm 1.2$ versus $50 \pm 5.3 \mathrm{pg} / \mathrm{ml})$ $(\mathrm{P} \leq 0.005)$ and also to animals with systemic inflammation without prior ovariectomy (group II $=42 \pm 3.5$

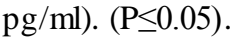

However, progesterone levels in group III (ovx+SI=14 $\pm 1.6 \mathrm{ng} / \mathrm{ml})$ were actually significantly higher from levels obtained in group II $(9 \pm 0.8$ $\mathrm{ng} / \mathrm{ml}$ ) and even group I (control $=11 \pm 0.9 \mathrm{ng} / \mathrm{ml}) .(\mathrm{P} \leq 0.05)$

Daily supplementation with estrogen after ovariectomy in group IV resulted in a significant increase in both estrogen $(63 \pm 4.1 \mathrm{pg} / \mathrm{ml})$ and progesterone levels $(19 \pm 4.2 \mathrm{ng} / \mathrm{ml})$ at time of measurement when compared to corresponding levels in groups (I, II and III). ( $\mathrm{P} \leq 0.05)$.

Daily supplementation with progesterone $(5 \mathrm{mg} / \mathrm{kg} \quad \mathrm{BW})$ after ovariectomy in group $\mathrm{V}$ resulted in a significant increase in progesterone levels in group $\mathrm{V}(36 \pm 1.8 \mathrm{ng} / \mathrm{ml})$ when compared to corresponding levels in groups $(\mathrm{I}=11 \pm 0.9 \mathrm{ng} / \mathrm{ml}$, $\mathrm{II}=9 \pm 0.8 \mathrm{ng} / \mathrm{ml}, \mathrm{III}=14 \pm 1.6 \mathrm{ng} / \mathrm{ml}$, and $\mathrm{IV}=19 \pm 4.2 \mathrm{ng} / \mathrm{ml}) .(\mathrm{B} \leq 0.005)$.

Estrogen levels in group V $(7 \pm 1.9$ $\mathrm{pg} / \mathrm{ml}$ ) were significantly lower in this group than corresponding levels in groups $\mathrm{I}=50 \pm 5.3 \mathrm{pg} / \mathrm{ml}, \quad \mathrm{II}=42 \pm 3.5$ $\mathrm{pg} / \mathrm{ml}$ and $\mathrm{IV}=63 \pm 4.1 \mathrm{pg} / \mathrm{ml}, \underline{\mathrm{R}} 0.005$ ).

Daily supplementation with both estrogen (dose 4ug/100g BW ) and progesterone $(5 \mathrm{mg} / \mathrm{Kg} \mathrm{BW})$ for three weeks in ovariectomized animals followed by induction of systemic inflammation (group VI) resulted in estrogen levels $(43 \pm 2.8 \mathrm{pg} / \mathrm{ml})$ similar to levels encountered in group

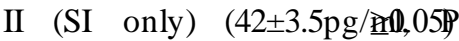
however, progesterone levels (38 \pm $0.9 \mathrm{ng} / \mathrm{ml}$ ) were significantly higher than those encountered in group II and even those in group I control group $(\mathrm{P} \leq 0.005)$ but did not differ significantly from values in group $\mathrm{V}$. $(P \geq 0.05)$ Figures (1) and (2).

TNF alpha, $C$ reactive protein and Serum ALT

Systemic inflammation induced in group II resulted in a significant increase in the serum levels of TNF $\alpha$, CRP and ALT when compared to control group. $(\mathrm{P} \leq 0.005)$

Systemic inflammation induced in group III ovariectomized animals resulted in a far more significant increase in the three measured markers when compared to their corresponding levels in both groups I and II. ( $\mathrm{P} \leq 0.005)$

Supplementation with Estradiol Benzoate for three weeks (4ug/100g BW) in ovariectomized animals (group IV) before induction of systemic inflammation resulted in a significant reduction in the levels of TNF $\alpha$, CRP and ALT when compared to their corresponding levels in groups II and IIE0.(PB5) though the markers did not return to their corresponding control levels encountered in group I.

Supplementation of ovariectomized animals with progesterone $(5 \mathrm{~m} / \mathrm{Kg} \mathrm{BW})$ for three weeks before induction of systemic inflammation resulted in a significant increase in the three markers of inflammation when compared to their 
corresponding levels in all the previous groups (I, II, III and IV) $(\mathrm{P} \leq 0.05)$.

Supplementation with both estradiol benzoate and progesterone for three weeks before induction of systemic inflammation in ovariectomized animals resulted in significant rise of $\mathrm{TNF} \alpha$ when compared to group IV receiving estradiol alone $\leq(\mathrm{P} .05)$. However, the levels of the CRP and ALT were not significantly altered from group IV receiving estradiol alone. ( $\mathrm{P} \geq 0.05)$

Group VI also showed a reduction in the level of inflammatory markers when compared to their corresponding levels in group II systemic inflammation without ovariectomy. ( $\mathrm{P} \leq 0.05)$.

(Table 1)

\section{iNOS, COX II and Caspase 3}

The expression of iNOs in liver tissue samples significantly increased in animals of group II subjected to systemic inflammation as compared to liver samples from group I. $(\mathrm{P} \leq 0.005)$. Expression of iNOS in ovariectomized animals later subjected to systemic inflammation was significantly higher when compared to samples taken from animals in group $\mathrm{II} \leq($ ए005).. The supplementation of ovariectomized animals with progesterone in group $\mathrm{V}$ significantly increased the level of expression of iNOS when compared to groups I, II and III ( $\mathrm{P} \leq 0.005)$.

In contrast, estrogen significantly reduced the level of expression of iNOS in liver samples taken from animals in group IV when compared to samples taken from groups II and III. $(\mathrm{P} \leq 0.005)$
The addition of progesterone to estrogen in ovariectomized animals did not significantly increase the level of expression of iNOS in group VI when compared to group IV receiving estrogen only or to the control group with no systemic inflammation or ovariectomy. ( $\mathrm{P} \geq 0.05$ ).

The activity of the two enzymes COXII and Caspase 3 significantly increased with systemic inflammation in liver tissue samples from group II when compared to corresponding results in group I. $(\mathrm{P} \leq 0.005)$

Ovariectomy followed by systemic inflammation in group III significantly increased the activity of both COXII and Caspase 3 in liver tissue samples when compared to corresponding values from samples of group II. $(\mathrm{P} \leq 0.005)$

Estradiol benzoate supplementation in group IV significantly reduced the level of activity of COXII when compared to group II (SI) $₫(\mathbb{P} .005)$, though the level was still significantly higher than corresponding value in group I. $(\mathrm{P} \leq 0.05)$.

The level of activity of Caspase in group IV receiving estrogen supplementation after ovariectomy before the induction of acute systemic inflammation was also highly significantly reduced when compared to corresponding values from groups II (SI), III $(\mathrm{Ovx}+\mathrm{SI}) \quad(\leq \mathrm{O} .0 \quad 05)$ and it almost returned to values in control group I $(\mathrm{P} \geq 0.05)$.

Group $\mathrm{V}$ that received progesterone supplementation after ovariectomy showed the highest level of activity of both COXII and Caspase 3 as values were significantly higher when compared to corresponding 
values obtained from all previous groups I, II, III and IV. (R्20.005)

The addition of progesterone with estradiol benzoate in group VI resulted in a significant increase in the levels of activity of COXII and Caspase 3 when compared to group IV receiving estrogen alone $(\mathrm{P} \leq 0.005)$. However, the values of
Caspase 3 obtained were still significantly lower than those obtained in group II non ovariectomized animals with systemic inflammation ( $\mathrm{B} \leq 0.05)$. The values of COXII obtained however were not significantly different from group II ( $\mathrm{P} \geq 0.05$ ) (Table 2, Figure3).

Table (1): Evaluation of TNF $\alpha$ (pg/ml), CRP (ug/ml) and ALT (IU/L) in serum samples taken from animals on the different groups studied at the end of experimental protocol. ( $\mathrm{n}=8$ in all groups)

\begin{tabular}{llll}
\hline Groups & TNF $\boldsymbol{\alpha}(\mathbf{p g} / \mathbf{m l})$ & CRP $(\mathbf{u g} / \mathbf{m l})$ & ALT $(\mathbf{I U} / \mathbf{L})$ \\
\hline Control & $11.1 \pm 0.887$ & $1.38 \pm 0.29$ & $45 \pm 10.3$ \\
\hline SI & $84.3 \pm 3.7^{\mathbf{a}}$ & $2.82 \pm 0.29^{\mathbf{a}}$ & $77.6 \pm 20.1^{\mathbf{a}}$ \\
\hline$. \mathrm{Ovx}+\mathrm{SI}$ & $94.6 \pm 4.44^{\mathbf{b}}$ & $3.73 \pm 0.31^{\mathbf{b}}$ & $89 \pm 10.4^{\mathbf{b}}$ \\
\hline Ovx+E+SI & $14.8 \pm 0.88^{\mathbf{c}}$ & $1.87 \pm 0.36^{\mathbf{c}}$ & $59 \pm 19.8^{\mathbf{c}}$ \\
\hline Ovx+P+SI & $104 \pm 3.3^{\mathbf{a}, \mathbf{b}, \mathbf{c}}$ & $4.88 \pm 0.58^{\mathbf{a}, \mathbf{b}, \mathbf{c}}$ & $100 \pm 12.8^{\mathbf{a , b , c}}$ \\
\hline Ovx+E+P+SI & $35.2 \pm 5.2^{\mathbf{d}}$ & $2.03 \pm 0.216^{\mathbf{b}}$ & $62 \pm 18.4^{\mathbf{b}}$ \\
\hline
\end{tabular}

Results are mean $\pm S D$.

SI: systemic inflammation, ovx = ovariectomy, $E=$ estradiol benzoate $(4 \mathrm{ug} / 100 \mathrm{~g} \mathrm{BW})$, $P=$ progesterone $(5 \mathrm{mg} / \mathrm{kg} \mathrm{BW})$.

a: Significant change in comparison with control group $I, P \leq 0.005$.

$b$ : Significant change in comparison with SI (group II) , $P \leq 0.005$.

c: Significant change in comparison with OvX+SI (group III),. $P \leq 0.005$.

$d$ : Significant change in comparison with OvX $+E+S I$ (group IV), $P \leq 0.0$

Table (2): Levels of expression of iNOS (ug/ml), and activity levels of COXII (U/ml) and Caspase $3(\mathrm{ng} / \mathrm{ml})$ in liver samples taken from experimental animals in different groups at the end of the experimental protocol. ( $\mathrm{N}=8$ in all groups)

\begin{tabular}{llll}
\hline Groups & iNOS (ug/ml) & COX II (U/ml) & Caspase 3 (ng/ml) \\
\hline Control & $180 \pm 23$ & $16.4 \pm 1.69$ & $0.98 \pm 0.228$ \\
\hline SI & $312 \pm 43^{\mathbf{a}}$ & $59.4 \pm 3.2^{\mathbf{a}}$ & $6.3 \pm 0.54^{\mathbf{a}}$ \\
\hline Ovx + SI & $543 \pm 65^{\mathbf{b}}$ & $69.3 \pm 2.35^{\mathbf{b}}$ & $7.47 \pm 0.39^{\mathbf{b}}$ \\
\hline Ovx $+\mathrm{E}+\mathrm{SI}$ & $193 \pm 28^{\mathbf{c}}$ & $27.6 \pm 3.91^{\mathbf{c}}$ & $1.18 \pm 0.21^{\mathbf{c}}$ \\
\hline Ovx $+\mathrm{P}+\mathrm{SI}$ & $690 \pm 73^{\mathbf{c}}$ & $81.9 \pm 3.58^{\mathbf{c}}$ & $9.6 \pm 0.59^{\mathbf{c}}$ \\
\hline Ovx $+\mathrm{E}+\mathrm{P}+\mathrm{SI}$ & $201 \pm 30^{\mathbf{c}}$ & $56.8 \pm 3.85^{\mathbf{d}}$ & $4.03 \pm 0.592^{\mathbf{b}, \mathbf{c}}$
\end{tabular}

Results are expressed as mean \pm S.D.

SI: systemic inflammation, Ovx= ovariectomy, $E=$ estradiol benzoate $(4 \mathrm{ug} / 100 \mathrm{~g} \mathrm{Bw})$, $P=$ progesterone $(5 \mathrm{mg} / \mathrm{kg} \mathrm{BW})$.

a: Significant change in comparison with control (group I), $P \leq 0.005$.

b: Significantly change in comparison with SI (group II) , $P \leq 0.005$.

c: Significant change in comparison with Ovx+SI (group III), $P \leq 0.005$.

$d$ : Significantly change in comparison with $\mathrm{Ovx}+E+S I$ (group IV), $P \leq 0.005$. 
Figure (1): The levels of Estrogen (pg/ml) measured in the serum of the different groups studied at the end of the experimental protocol. ( $\mathrm{n}=8$ in all groups)

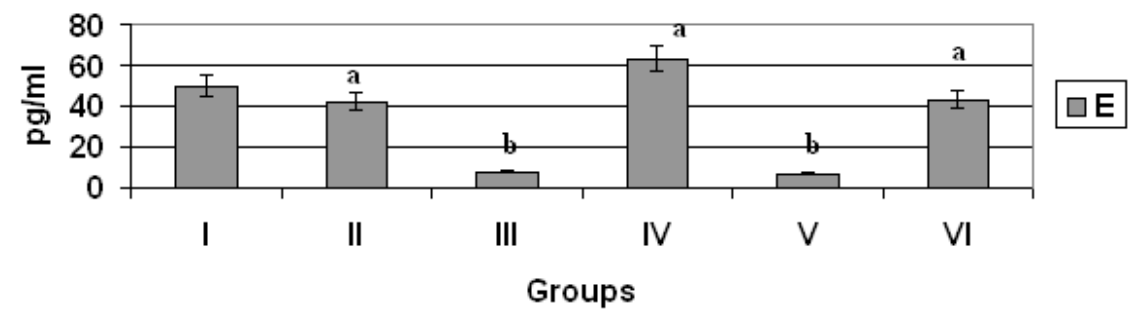

Group $I=$ Control, Group $I I=S I$, Group $I I I=O v x+S I, I V=O v x+E+S I, V=O v x+P+S I$, $V I=O v x+E+P+S I$,

$E=$ Estrogen, $S I=$ Systemic inflammation, $O v x=$ ovariectomy, $P=$ Progesterone

$a=$ significant change in comparison with group I, $P \leq 0.05$

$b=$ significant change in comparison with group II, $P \leq 0.005$

Figure (2): The levels of Progesterone ( $\mathrm{ng} / \mathrm{ml}$ ) measured in the serum of the different groups studied at the end of the experimental protocol. ( $\mathrm{n}=8$ in all groups)

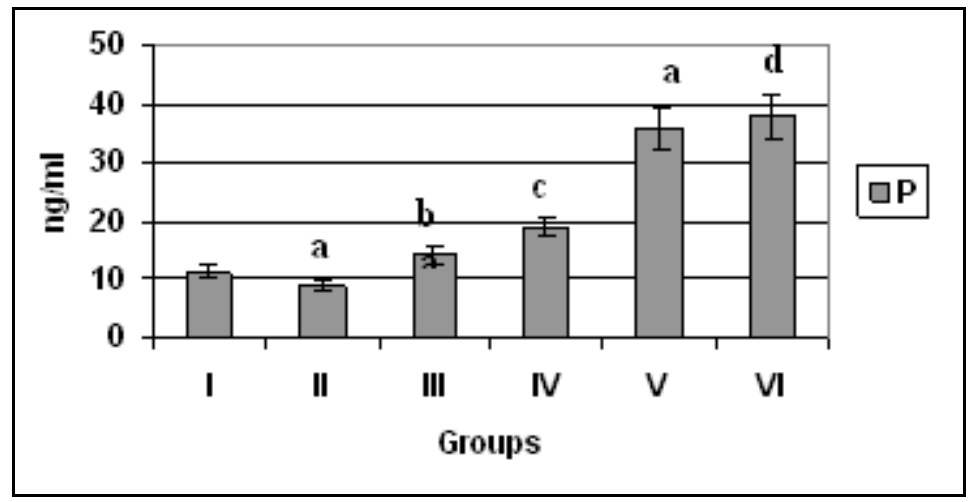

Group $I=$ Control, Group $I I=S I$, Group $I I I=O v x+S I, I V=O v x+E+S I, V=O v x+P+S I$, $V I=v x+E+P+S I, E=$ Estrogen, $S I=$ Systemic inflammation, Ovx= ovariectomy, $P=$ Progesterone

$a=$ significant change in comparison with group $I, P \leq 0.05$

$b=$ significant change in comparison with group II, $P \leq 0.005$

$c=$ significant change in comparison with group III, $P \leq 0.05$

$d=$ significant change in comparison to group $I V, P \leq 0.005$. 
Figure (3): An agarose gel electrophoresis showing PCR products of iNOS gene from liver samples obtained from different groups studied.

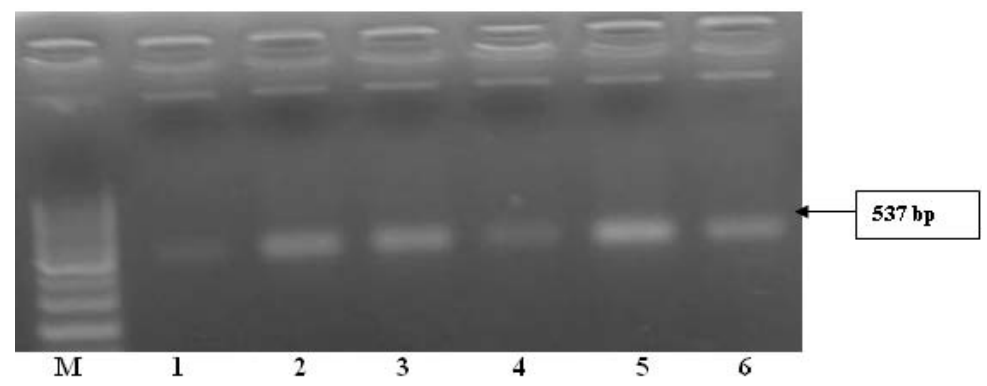

Lane M : PCR marker with 100 bp ladder

Lane 1: PCR products of iNOS gene in control group

Lane 2: PCR products of iNOS gene in $0 v x+$ SI group

Lane 3: PCR products of iNOS gene in SI group

Lane 4: PCR products of iNOS gene in Ovx $+S I+E$ group

Lane 5: PCR products of iNOS gene in $\mathrm{OvX}+\mathrm{SI}+\mathrm{P}$ group

Lane 6: PCR products of iNOS gene in $\mathrm{OvX}+\mathrm{SI}+\mathrm{E}+\mathrm{P}$ group

\section{DISCUSSION}

Our results showed that induction of systemic inflammation in intact non ovariectomized animals led to a significant increase in the levels of inflammatory markers, $\mathrm{TNF} \alpha, \mathrm{C}$ reactive protein as well as liver enzymes in the serum of animals.

This was associated with increased expression of iNOS, and activity of COX II and Caspase 3 enzymes in liver tissue samples and also a significant reduction of serum estrogen and progesterone levels when compared to control levels.

Patel et al in $2003^{(20)}$ found that LPS from bacterial sepsis causes endothelial activation with upregulation of adhesion molecules, and promotes the release cytokines, including tumor necrosis factor- $\alpha$ (TNF $\alpha$ ), interleukin-6 (IL-6) and interferon- $\gamma$ (IFN $\gamma$ ), which typically increase in sequence

It is generally accepted that proinflammatory cytokines, especially TNF- $\alpha$, are critical for the pathophysiology and subsequent complications of exaggerated inflammatory response. TNF- $\alpha$ alone or in combination with IL-1 and complement is responsible for neutrophil transmigration and sequestration in hepatic sinusoids during endotoxemia and sepsis ${ }^{(21)}$. Neutrophils attack parenchymal cells and cause severe liver cell necrosis ${ }^{(22)}$. TNF- $\alpha$ also leads to the production of the transcription nuclear factor NF$\kappa \mathrm{B}$ in endothelial cells and hepatocytes during endotoxemia (23). $\mathrm{NF}-\kappa \mathrm{B}$ is then responsible for the transcriptional activation of a number of proinflammatory genes such as nitric oxide synthase ${ }^{(24)}$, and adhesion 
molecules such as ICAM-1, selectins ${ }^{(25)}$ and VCAM- ${ }^{(26)}$.

The significant increase in COXII activity that we found in group II (Systemic inflammation group) can play a complicating role in inflammation as it has been reported that COX-2 pathway prostanoids can increase pulmonary and reduce systemic vascular resistance, features which greatly impair the body response to systemic sepsis. ${ }^{(27)}$

Our observation that systemic inflammation in group II was associated with a reduction of sex hormones can be partly interpreted by a role played by the observed significant increase in iNOS expression. It has been suggested that iNOS can be expressed in moderate to high levels in brain tissue in infectious or inflammatory conditions. High NO levels may also result in feedback inhibition of NOS activity and/or expression ${ }^{(28)}$ and also elicit a direct inhibition of GnRH synthesis. The latter may occur through the interaction with an element in the $\mathrm{GnRH}$ gene promoter that is repressed by the NO-mediated cGMP signal transduction pathway ${ }^{(29)}$.

It has also been suggested that inflammatory markers such as IL1 are involved in the immune system and have a role in ovarian inflammation as well $s$ exhibiting a direct inhibitory effect on the ovarian steroidogenes is and folliculogenesis ${ }^{(30)}$, a finding which may further reduce the production of the measured hormones in group II animals when compared to the control group.

A rather surprising finding was that in group III systemic inflammation in ovarietomized animals, there was actually an increase in serum progesterone to levels higher than control group or group II (animals with systemic inflammation).

Our results can be interpreted by the findings of Flores et al. $2008^{(31)}$ who suggested that the adrenals are the main source of progesterone in rats while the ovaries are the main source of estradiol and testosterone during the cycle. They also suggested that a ventral approach to ovariectomy as the one we used in our experiments results in higher levels of observed progesterone levels when compared to a dorsal approach due to stimulation of neural pathways arising from the dorsal and ventral peritoneum. .

There is strong evidence that stress increases the activity of the hypothalamic-pituitary-adrenal (HPA) axis, through the increase in CRF that in turn stimulates $\mathrm{ACTH}$ and $\beta$ endorphin secretion, while ACTH stimulates the adrenal corticosteroids secretion. If the surgical stress of ovariectomy can increase adrenal corticosteroids secretion and as the adrenals are responsible for progesterone secretion during the cycling rat, it is thus possible to assume that increased progesterone levels can be encountered under such circumstances. Flores et al $2005{ }^{(32)}$ also suggest that the response capacity to stress by the hypothalamus pituitary-adrenal axis can be manifested by increasing progesterone secretion.

Supplementation of the ovariectomized animals with daily subcutaneous $4 \mu \mathrm{g} / 100 \mathrm{~g}$ BW estradiol benzoate resulted in a serum levels of estrogen and progesterone that is 
within the range of the diestrus./porestrus levels found in normal cycling rats though higher than the mean level achieved in our control group and also suggesting a positive effect of estrogen supplementation on the peripheral mechanisms controlling progesterone formation, a finding which was also reported in the study of Sunday et al.in 2006. ${ }^{\text {(10) }}$

Supplementation ovariectomized animals with a $4 \mu \mathrm{g} / 100 \mathrm{~g}$ BW daily estradiol benzoate therapy before induction of acute systemic inflammation resulted in a significant reduction in TNF $\alpha, \mathrm{C}$ reative protein and ALT when compared to group III ovariectomized animals that received no hormonal supplementation before induction of systemic inflammation. Our results agree with Asai et al. ${ }^{(33)}$ who found that in the presence of LPS (at $1 \mathrm{ng} / \mathrm{ml}$ $\mathrm{EC}_{50}$ of LPS), estradiol inhibited TNFa in both male and female subjects, but E2 had a stimulating effect in the absence of LPS.

According to Straub ${ }^{(34)}$, the effect of estrogen as pro-inflammatory or anti-inflammatory is greatly affected by several factors, namely, the type of stimulus whether it is a foreign or an auto-antigen and subsequent antigenspecific immune responses, for example estrogens seem to produce $\mathrm{T}$ cell inhibition and $\mathrm{B}$ cell activation. The effect of estrogen is also different depending on the target organ with its specific microenvironment; the timing of $17 ß$-estradiol administration in relation to the disease course and the reproductive status of a woman; the concentration of estrogens; the variability in expression of estrogen receptor alpha and $\beta$ in the organ studied; and the intracellular metabolism of estrogens leading to important biologically active metabolites with quite different antiand pro-inflammatory function.

Our results of the effect of estrogen on liver inflammation are supported by the findings of $\mathrm{Xu}$ et al. ${ }^{(35)}$ who reported that E2 treatment for 8 weeks to proestrus levels reduced aspartate aminotransferase, alanine aminotransferase, hyaluronic acid, and type IV collagen in sera and lowered the synthesis of hepatic type I collagen significantly in both sexes, an effect which is blocked by tamoxifen.

Our results in group IV of animals supplemented by estrogen for three weeks after ovariectomy before induction of systemic inflammation showed a significant reduction of iNOS expression and Caspase III and COX II activity.

Weiner et al. $^{(36)}$ found that estrogen enhanced nitric oxide (NO) production, however this was the result of activation of the endothelial is oform of the enzyme NO synthase (NOS) and this activation seems to occur when no inflammatory mediator influence is involved.

In contrast, it has been documented that E2 at pregnancy levels inhibit LPS-induced TNF- $\alpha$ and NO production in primary rat microglia and mouse N9 microglial cells via iNOS inhibition ${ }^{(37)}$. Similar effects have been noticed in aortic endothelial cells and pleural cells in conditions of inflammation. ${ }^{(38)}$.

However, this inhibition seems to relate to the duration also of estrogen suppelementation before LPS are 
injected in the animals as short durations of one day extending to one week treatment after ovariectomy were associated with higher levels of iNOS and TNF $\alpha$ levels after the LPS challenge. ${ }^{(39)}$

Our results of the effect of estrogen in the dose used on the expression of caspase 3 in the rat model have also been reported in human peripheral $\mathrm{T}$ lymphocytes by Takao et al. ${ }^{(\mathbf{4 0})}$ where E2 at periovulatory to pregnancy levels for periods as short as $24 \mathrm{~h}$ reduced caspase 3 activity, which must be viewed as a strong and quick antiapoptotic effect.

However, Acconicia et al. $^{(41)}$ suggest that the E2-ER complex can activate both apoptotic and antiapoptic pathways according to the prevalence to either estrogen receptor apha $(\alpha)$ or beta $(\beta)$ in the studied cell line. E2-ER $\alpha$ rapidly activates multiple signaling pathways (i.e., ERK/MAPK, phosphotidylinositol 3kinase/Akt) committed to both cell cycle progression and prevention of apoptotic cascades. On the other hand, the E2-ERß complex induced the rapid and persistent phosphorylation of p38/MAPK, which in turn was involved in caspase 3 activation and cleavage of poly (ADP-ribose) polymerase, driving cells into the apoptotic cycle. E2 at $10^{-8} \mathrm{M}$ promotes cell survival through ER- $\alpha$ non-genomic signalling and cell death through ERß nongenomic signaling . Thus, the influence of E2 would be dependent on the abundance of either $\mathrm{ER} \alpha$ or ERß.

In summary, our results seem to favour the view that estrogen in the dose used and for prolonged duration led to a generalised reduction in inflammatory markers especially the important mediators $\mathrm{TNF} \alpha$ and $\mathrm{iNOS}$ and promoted an anti-apoptotic effect through inhibition of the action of Caspase 3 in liver tissue possibly promoting a generalised protective effect during states of acute systemic inflammation involving the liver tissue.

In contrast, our results suggest that progesterone in the dose used in group $\mathrm{V}(\mathrm{Ovx}+\mathrm{SI}+\mathrm{P})$ achieved a serum level as the levels usually encountered in the estrus part of the normal cycling female rat. ${ }^{(42)}$. This level was associated with a generalised increase in inflammatory markers $\mathrm{TNF} \alpha, \mathrm{C}$ reactive protein, ALT in serum and, iNOS expression, COXII activity as well as Caspase 3 activity in liver tissue.

The addition of progesterone to estrogen partially counteracted the anti-inflammatory and anti-apoptotic effect of estrogen. Our results are similar to the results of Sunday et $\mathrm{al}^{(\mathbf{1 0 )}}$ in brain vascular tissue. The researchers found that progesterone alone exacerbated the inflammatory response to LPS. In combination with estrogen, progesterone partially reversed the anti-inflammatory effects of estrogen in brain vascular tissue.

However, in models of traumatic brain injury, exogenous progesterone $(4 \mathrm{mg} / \mathrm{kg})$ in male rats has been shown to reduce secondary neuronal loss and to attenuate brain edema ${ }^{(43)}$, independent of estrogen. The administration of progesterone (4 to $10 \mathrm{mg} / \mathrm{kg}$ ) before or after the onset of transient focal cerebral ischemia in male rats or of global ischemia in ovariectomized cats greatly reduced 
ischemic cell damage and neurological deficits ${ }^{(\mathbf{4 4})}$.

However, it is possible that the distribution of progesterone receptors in the male rat and in the cat is different from that observed in the female rat. Also, the effects of progesterone might be through other pathways that work independent of inflammation and apoptosis. It is also possible that the short duration of treatment could also influence the final effect of progesterone treatment suggesting that progesterone protective effects might be present at very closely monitored ranges of plasma with a potential for exacerbation of the inflammatory response if more prolonged durations of treatment are used.

In conclusion, we have found that the use of external estradiol benzoate in the doses and durations suggested in the ovariectomised female rats achieved levels similar to those found physiologically in proestrous and diestrous animals and resulted in a significant reduction of systemic and liver inflammatory and apoptotic markers in a model of acute systemic inflammation. Progesterone in the dose and duration used has achieved levels again as seen in the estrous phase of the rat cycle and resulted in exacerbation of inflammatory mediators and liver affection and tendency for apoptosis.

As the roles of estrogen an progesterone seem to be depending greatly on the dose used and the organ studied, more research is required to further eluciate the effects of such important hormones which might prove valuable tools in controlling the serious and frequently fatal effects of systemic endotoxemia and shock.

\section{REFERENCES}

1. Darlington GJ, Wilson DR, Revel M, Kelly JH. (1989): Response of liver genes to acute phase mediators. Ann N Y Acad Sci., 557:310-5; discussion 3156.

2. Berbee JF, Havekes LM, Rensen PC. (2005):

Apolipoproteins modulate the inflammatory response to lipopolysaccharide. J Endotoxin Res., 11:97-103.

3. Marshall JC. (2001): Inflammation, coagulopathy, and the pathogenesis of multiple organ dysfunction syndrome. Crit Care Med., 29:S99-S106

4. Eipel $C$, Bordel R, Nickels RM, Menger $\mathrm{MD}$ and Vollmar $\mathrm{B}$. (2004): Impact of leukocytes and platelets in mediating hepatocyte apoptosis in a rat model of systemic endotoxemia. Am J Physiol., 286:G769-G776.

5. Jaeschke $H$, Fisher MA, Lawson JA, Simmons CA, Farhood A. and Jones DA. (1998): Activation of caspase 3 (CPP32)-like proteases is essential for TNF-alpha-induced hepatic parenchymal cell apoptosis and neutrophilmediated necrosis in a murine endotoxin shock model. J Immunol., 160:3480-3486.

6. Khoi LM, Katja K, Kerstin A,Christian E, Michael DM and Vollmar B. (2007): Attenuation of Inflammation and Apoptosis by Pre- and 
Posttreatment of Darbepoetin- in Acute Liver Failure of Mice. American Journal of Pathology, 170:1954-1963.

7. Cushman M, Legault C, Barrett-Connor E, Stefanick ML, Kessler C, Judd HL, Sakkinen PA, Tracy RP. (1999): Effect of postmenopausal hormones on inflammationsensitive proteins: the Postmenopausal Estrogen/ Progestin Interventions (PEPI) Study. Circulation., 100: 717722.

8. Herrington DM, Brosnihan KB, Pusser BE, Seely EW, Ridker PM, Rifai N, MacLean DB. (2001): Differential effects of $E$ and droloxifene on C-reactive protein and other markers of inflammation in healthy postmenopausal women. $\mathrm{J}$ Clin Endocrinol Metab., 86: 42164222.

9. Wakatsuki A, Ikenoue $\mathbf{N}$, Shinohara $K$, Watanabe $K$ and Fukaya T. (2004): Effect of Lower Dosage of Oral Conjugated Equine Estrogen on Inflammatory Markers and Endothelial Function in Healthy Postmenopausal Women. Arteriosclerosis, Thrombosis, and Vascular Biology., 24:571.

10. Sunday L,Tran MM, Krause DN, and Duckles SP. (2006): Estrogen and progestagens differentially modulate vascular proinflammatory factors. Am J Physiol Endocrinol Metab., 291: E261-E267.

11. Rosano GM, Webb CM, Chierchia S, Morgani GL, Gabraele M, Sarrel PM, de
Ziegler D, and Collins $P$. (2000): Natural progesterone, but not medroxyprogesterone acetate, enhances the beneficial effect of estrogen on exercise-induced myocardial ischemia in postmenopausal women. $J$ Am Coll Cardiol 3.,6: 2154-2159.

12. Kautshic C, Zhou F, Murdin $\mathrm{AD}$, and Wira CR. (2000): Effects of Estradiol and Progesterone on Susceptibility and Early Immune Responses to Chlamydia trachomatis Infection in the Female Reproductive Tract. Infect Immun., 68(70): 42074216.

13. Mizutani A, Okajima $K$, Uchiba $M$, Isobe $M$, Haroda $N$, Mizulani $S$ and Noguchi $T$. (2003): Anti-thrombin reduces ischemia reperfusion induced renal injury in rats by inhibiting leucocyte activation through promotion of protacyclin production. Hemostasis, thrombosis and vascular biology, 101 (6): 3029-36.

14. Gewurz H, Mold C, Siegel J. and Fiedle B. (1982): C reactive protein and the acute phase response. Adv. Intern. Med., 27: 345-72.

15. Johns on MR, Carter G, Grint $C$ and lightinson SI (1993): Relationship between ovarian steroids, gonadotrophin and relaxin during the menstrual cycle. Acta endocrinology, 129: 121-125.

16. Hilborn $S$ and Krahn J. (1987): Effect of time of exposure of serum to gel barrier tubes on results for progesterone and some 
other endocrine tests. Clinical biochermistry, 33: 203-209.

17. Chumzanski $P$ and Sacchi $C$. (1987): Single step method of RNA isolation by guanidium thiocyanate phenol chloroform extraction. Anal. Biochem., 162: 156-159.

18. Tsai HW, and Legan SJ. (2002): Loss of Luteinizing Hormone Surges Induced by Chronic Estradiol Is Associated with Decreased Activation of Gonadotropin-Releasing Hormone Neurons. Biology of Reproduction, 66: 1104-1110.

19. Fink MP, Heard SO. (1990): Laboratory models of sepsis and septic shock. J Surg Res., 49(2): 186-96.

20. Patel GP, Gurka DP, Balk RA (2003): New treatment strategies for severe sepsis and septic shock. Curr Opin Crit Care, 9:390-396 .

21. Jaeschke H., Farhood A, Fisher MA, Smith CW. (1996): Sequestration of neutrophils in the hepatic vasculature during endotoxemia is independent of $\beta_{2}$ integrins and intercellular adhesion molecule-1. Shock, 6:345.

22. Chosay JG, Essani NA, Dunn CJ, Jaeschke H. (1997): Neutrophil margination and extravasation in sinusoids and venules of the liver during endotoxin-induced injury. Am. J. Physiol., 272:G1195.

23. Essani N A., McGuire GM, Manning AM, Jaeschke $H$. (1996): Endotoxin-induced activation of the nuclear transcription factor $\kappa \mathrm{B}$ and expression of E-selectin messenger RNA in hepatocytes, Kupffer cells, and endothelial cells in vivo. J. Immunol., 156:2956.

24. Geller DA, de Vera ME, Russell DA , Shapiro RA, Nussler AK, Simmons RL, Billiar TR. (1995): A central role for the IL$1 \beta$ in the in vitro and in vivo regulation of hepatic inducible nitric oxide synthase. J. Immunol., 155:4890

25. Essani NA, McGuire GM, Manning AM, Jaeschke $H$. (1995): Differential induction of mRNA for ICAM-1 and selectins in hepatocytes, Kupffer cells and endothelial cells during endotoxemia. Biochem. Biophys. Res. Commun., 211:74

26. Essani, NA, Bajt ML, Vonderfecht SL, Farhood A, Jaeschke H. (1997): Transcriptional activation of vascular cell adhesion molecule-1 (VCAM-1) gene in vivo and its role in the pathophysiology of neutrophil-induced liver injury in murine endotoxin shock. J. Immunol.., 158:5941.

27. Baber SR,Champion HC, Bivalacqua TJ, Hyman AL, Kadowitz PJ. (2003): Role of Cyclooxygenase-2 in the Generation of Vasoactive Prostanoids in the Rat Pulmonary and Systemic Vascular Beds. Circulation,108:896.

28. Canteros G, Rettori V, Genaro A, Suburo A, Gimeno $M$, McCann SM. (1996): Nitric oxide synthase content of hypothalamic explants: increase by norepinephrine and inactivated 
by $\mathrm{NO}$ and cGMP. Proc Natl Acad Sci. USA, 93:4246-4250.

29. Belsham DD, Wetsel WC, Mellon PL. (1996): NMDA and nitric oxide act through the cGMP signal transduction pathway to repress hypothalamic gonadotropin-releasing hormone gene expression. EMBOJ., 15: 538-547.

30. Deok-Soo Son and Katherine F. Roby.(2006): Interleukin-1Induced Chemokines in Mouse Granulosa Cells: Impact on Keratinocyte Chemoattractant Chemokine, a CXC Subfamily. Molecular Endocrinology, 20 (11): 2999-3013.

31. Flores A, Gallegos A, Velasco J, De Mendoza F, Montiel C, Everardo P, Cruz ME, and Domínguez R.( 2008): The acute effects of bilateral ovariectomy or adrenalectomy on progesterone, testosterone and estradiol serum levels depend on the surgical approach and the day of the estrous cycle when they are performed. Reprod Biol Endocrinol., 6: 48

32. Flores A, Melendez G, Palafox MT, Rodriguez JO, Barco AI, Chavira R, Dominguez R, Cruz ME (2005): The participation of the cholinergic system in regulating progesterone secretion through the ovarian-adrenal crosstalk varies along the estrous cycle. Endocrine, 28:145-151.

33. Asai K, Hiki N, Mimura $Y$, Ogawa T, Unou $K$, Kaminishi M. (2001): Gender differences in cytokine secretion by human peripheral blood mononuclear cells: role of estrogen in modulating LPS-induced cytokine secretion in an ex vivo septic model. Shock 16:340-343.

34. Straub RH. (2007): The Complex Role of Estrogens in Inflammation. Endocrine Reviews, 28 (5): 521-574.

35. Xu JW, Gong J, Chang XM, Luo JY, Dong L, Hao ZM, Jia A, Xu GP. (2002): Estrogen reduces CCL4- induced liver fibrosis in rats. World $\mathrm{J}$ Gastroenterol., 8:883-887.

36. Weiner CP, Lizasoain I, Baylis SA, Knowles RG, Charles IG, Moncada S. (1994): Induction of calcium-dependent nitric oxide synthases by sex hormones. Proc Natl Acad Sci USA., 91:52125216.

37. Drew PD, Chavis JA. (2000): Female sex steroids: effects upon microglial cell activation. J Neuroimmunol 1.,11:77-85.

38. Vegeto E, Pollio G, Ciana $P$, Maggi A. (2000): Estrogen blocks inducible nitric oxide synthase accumulation in LPSactivated microglia cells. Exp Gerontol., 35:1309-1316.

39. Ikejima $K$, Enomoto $N$, limuro Y, Ikejima A, Fang D, Xu J, Forman DT, Brenner DA, Thurman RG. (1998): Estrogen increases sensitivity of hepatic Kupffer cells to endotoxin. Am J Physiol 274:G669-G676.

40. Takao T, Kumagai C, Hisakawa N, Matsumoto R, Hashimoto K. (2005): Effect of 17ß-estradiol on tumor necrosis factor--induced cytotoxicity in the human peripheral $\mathrm{T}$ lymphocytes. J Endocrinol., 184:191-197. 
41. Acconcia F, Totta $P$, Ogawa $S$, Cardillo I, Inoue S, Leone S, Trentalance A, Muramatsu M, Marino M. (2005): Survival versus apoptotic 17ß-estradiol effect: role of ER and ER $\beta$ activated non-genomic signaling. J Cell Physiol., 203:193-201.

42. Butcher RL, Collins WE, Fugo NW. (1974): Plasma concentrations of LH, FSH, prolactin, progesterone and estradiol-17ß throughout the 4day estrous cycle of the rat. Endocrinology, 94:1704-1708.
43. Roof RL, Duvdevani R, Stein DG (1993): Gender influences outcome of brain injury: progesterone plays a protective role. Brain Res., 607:333-336.

44. Gonzalez-Vidal MD, CerveraGaviria M, Ruelas R, Escobar A, Morali G, Cervantes $M$. (1998): Progesterone: protective effects on cat hippocampal neuronal damage due to acute global cerebral ischemia. Arch Med Res., 29:117-124.

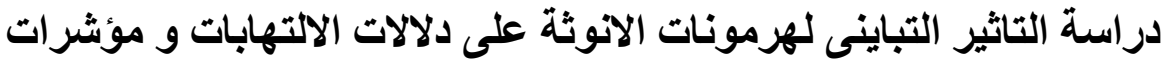

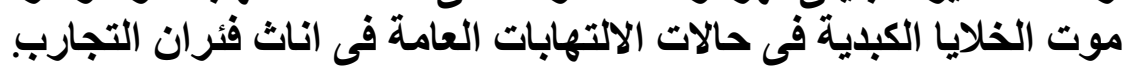

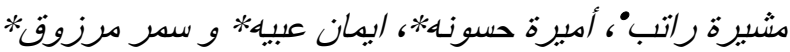

قسم الفسيولجيا" و قسم الكيمياء الحيوية الطبية*، كلية الطب جانب جامعة القاهرة.

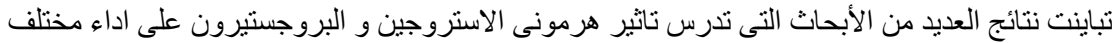

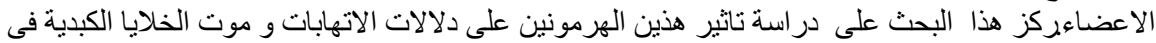

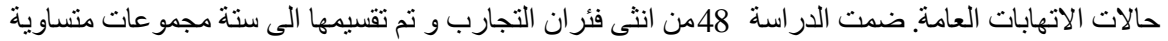

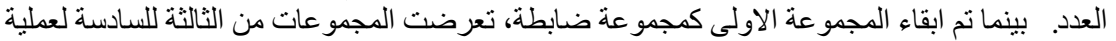

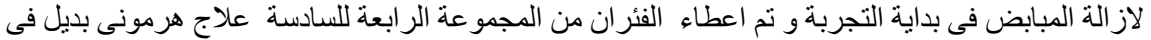

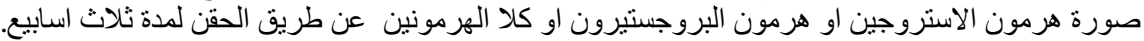

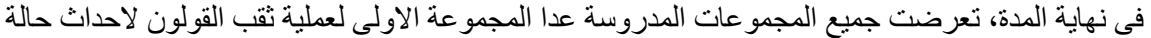

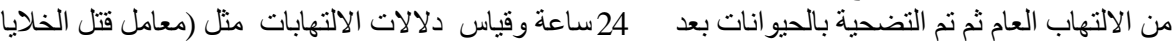

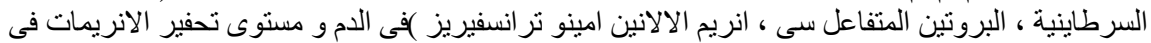

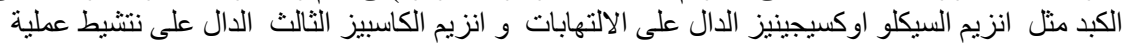

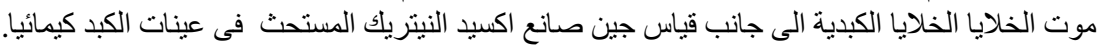

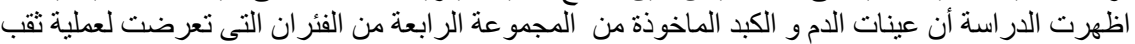

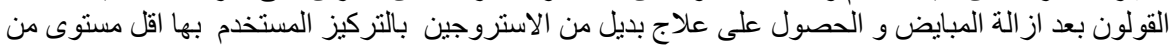

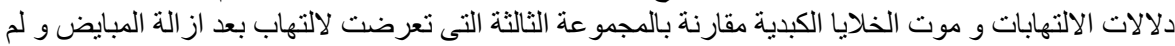

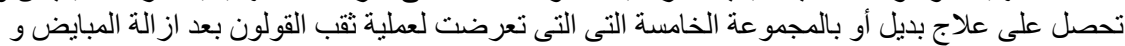

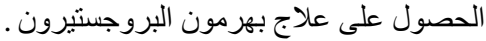

نستخلص من هذه الدراسة أن هرمون الاستروجين بالترون بالتركيز المستخدم و للفترة المستخدمة ادى الى تقليل

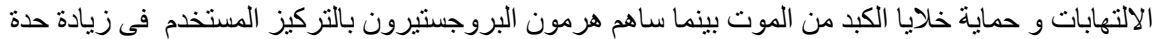

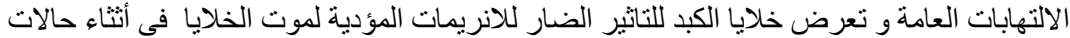

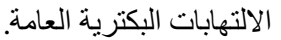

